\title{
W stronę dialogu - o modelach, wymiarach i strategiach komunikacyjnych
}

\author{
Towards dialogue - about models, dimensions \\ and communication strategies
}

\author{
Małgorzata Rzeszutko-Iwan \\ Centrum Języka i Kultury Polskiej dla Polonii i Cudzoziemców, \\ Uniwersytet Marii Curie-Skłodowskiej w Lublinie, \\ ul. Weteranów 18, 20-138 Lublin, Polska; \\ e-mail: malgorzatarzeszutko@wp.pl
}

\begin{abstract}
Abstrakt
Przedmiotem opisu jest ukazanie potencjalnych uwarunkowań sprzyjających harmonijnemu porozumiewaniu się oraz czynników utrudniających fortunną komunikację. Próba ta została przedstawiona w kontekście wybranych modeli komunikacji, wymiarów procesu komunikowania oraz strategii komunikacyjnych. Komunikacji rozumianej jako całościowy i wszechobecny przekaz treści (informacji, emocji itp.) można przypisać następujące cechy: interakcyjność, nastawienie na drugą stronę, dialogowość, intencjonalność itp.
\end{abstract}

Słowa kluczowe: dialog; komunikacja; modele komunikacji; wymiary komunikacji; strategie komunikacyjne.

\begin{abstract}
This article focuses on the potential conditions which are conducive to harmonious communication and the factors hampering desirable contact. It is presented in the context of selected models of communication, the dimensions of the communication process and communication strategies. Communication is interpreted here as comprehensive and omnipresent content (information, emotions etc.). It can be associated with the following characteristics: interactivity, orientation to the other party, entering into a dialogue, intentionality etc. An attempt at identifying conditions conductive to the desirable contact will be presented in the context of the selected models, the dimensions of the communication process and communication strategies.
\end{abstract}

Keywords: dialogue; communication; communication models; communication dimensions; communication strategies.

Komunikacja stanowi jedną z podstawowych potrzeb człowieka. Nie jest możliwe „rozpoznanie jakiejkolwiek ludzkiej interakcji, struktury, organizacji, czy nawet kultury, której istnienie, utrzymanie się i dalsze trwanie nie byłoby całkowicie zależne od komunikacji”. Komunikowanie się jest ,jedynym sposobem 
ustanawiania i utrzymywania instytucji ludzkich, włączając kultury" (Casmir 1996b: 17-18) $)^{1}$. Ma tym samym zawsze wymiar społeczny². Nie jest możliwa izolacja zarówno pomiędzy jednostkami, jak i całymi narodami, kręgami kulturowymi.

Celem artykułu jest ukazanie potencjalnych uwarunkowań sprzyjających harmonijnemu porozumiewaniu się oraz czynników utrudniających fortunną komunikację. Próba ta została przedstawiona w kontekście wybranych modeli komunikacji, wymiarów procesu komunikowania oraz strategii komunikacyjnych.

\section{Modele i wymiary komunikacji}

Komunikacja postrzegana jest przez pryzmat wielu kategorii, wskazujących na różne aspekty. Warto zatem przytoczyć kilka przykładów opisu tego pojęcia:

- komunikacja jako transmisja - „Komunikowanie to przekazywanie informacji w bardzo szerokim znaczeniu tego terminu”; „Przekazywanie informacji, idei, emocji, umiejętności etc. To właśnie akt lub proces transmisji jest zazwyczaj nazywany komunikowaniem";

- komunikacja jako rozumienie - „Komunikowanie jest procesem, dzięki któremu rozumiemy innych i z kolei sami staramy się być zrozumianymi”; „Proces, przez który dwie osoby dochodzą do tych samych myśli lub uczuć";

- komunikacja jako oddziaływanie - „Słowa tego używamy do określenia wszystkich sposobów, którymi ludzie oddziaływają na siebie”; „Użycie znaków i symboli, dzięki którym sprawuje się władzę";

- komunikacja jako łączenie (tworzenie wspólnoty) - „Proces, który łączy nieciągłe części naszego żyjącego otoczenia”; ,Tworzenie społecznej całości z jednostek przy użyciu języka lub znaków";

- komunikacja jako interakcja - „Społeczna interakcja za pomocą symboli”;

- komunikacja jako wymiana - „Wymiana znaczeń między ludźmi jest możliwa w stopniu, w jakim jednostki mają wspólne postrzeżenia, pragnienia i postawy";

- komunikacja jako składnik procesu społecznego - „Akt komunikatywny jest środkiem, przez który są wyrażane normy grupowe, sprawowana kontrola społeczna, przydzielane role, osiągnięta koordynacja wysiłków, są ujawniane oczekiwania i przenoszony proces społeczny"3.

${ }^{1}$ Por. też podejście pankomunikacjonizmu - teorii o powszechności komunikacji i komunikowania oraz niemożności przerwania tego procesu; założenia szkoły Palo Alto (Watzlawick, Beavin, Jackson 1967; Skibiński 2003).

${ }^{2}$ Por. Dobek-Ostrowska 2002: 14-15; Kaczmarek 2009: 11; Kudra 2014: 9. Zob. też komunikacyjną wizję społeczeństwa J. Habermasa (1999, 2002).

${ }^{3}$ Wszystkie ww. definicje cyt. za Goban-Klas 2002: 42-43. Komunikacja bywa też traktowana jako synonim kultury (Hall 1987, 2001; Carey 1989). Por. także nt. komunikacji: ujęcie systemowo- 
Komunikacja rozumiana jest tym samym jako całościowy i wszechobecny przekaz treści (informacji, emocji itp.). Tak pojmowana ma następujące cechy:

a) intencjonalność (intencja komunikacyjna: intencja nadawania, intencja odbiorcza),

b) celowościowość (np. posiadanie przewagi, władzy, tworzenie wspólnoty, zapewnienie porządku),

c) nastawienie na drugą stronę (partnera, osobę, uczestnika),

d) interakcyjność (przebieg sprzężenia zwrotnego),

e) dialogowość,

f) wspólnotę kontekstu (wiedza o świecie, kultura, wartości, świadomość itp.),

g) skuteczność.

Bardzo ważna jest świadomość tego, że nadawane komunikaty zbudowane są z elementów, które nadawca chce świadomie (intencjonalnie) przekazać, lecz również i z takich, które podaje nieświadomie, a odbiorca może, umie, chce lub powinien odczytać. Błędne tym samym jest przekonanie, że nadawca komunikuje tylko te informacje, które zamierza przesłać odbiorcy. Warto w tym miejscu przywołać także, wywodzące się z myśli greckiej, aksjomaty, na których opiera się proces komunikacji:

1) prymat nadawcy,

2) doniosłość rozumu, logiki, perswazji,

3) akceptacja wzorców opartych na dyskusji, konfrontacji, argumentowaniu, negocjowaniu stron,

4) postrzeganie za pożądany cel wyniku określonego w kategoriach zwycięstwa/porażki.

Jak wiadomo, proces komunikacji obejmuje triadę: nadawca (twórca), przekaz (wytwór), odbiorca. Układ parametrów komunikacji jest jednak szerszy i dotyczy ponadto:

1) intencji i celu,

2) kodowania,

3) kanału (bezpośrednia, pośrednia),

4) dekodowania,

5) funkcji,

6) sprzężenia zwrotnego (jednostronna, dwustronna),

7) sytuacji i kontekstu (oficjalna, nieoficjalna),

8) uwarunkowań społeczno-kulturowych.

-pragmatyczne Szkoły Palo Alto (Watzlawick, Beavin, Jackson 1967); ujęcie systemowe (Fisher 1982); teorię reguł społecznych (Crushman, Valentinsen, Dietrich 1982); teorię konstruktywistów, symboliczny interakcjonizm, teorię samoświadomości (Nęcki 2000). Zob. też Andrzejewski 1990; Szacka red. 1991; Korporowicz 1993.

${ }^{4}$ Zob. Arystoteles 1988; Casmir 1996a: 30-31; Żydek-Bednarczuk 2005: 14-28; Stalmaszczyk, Cap red. 2014. 
Przywołane parametry komunikacyjne kształtują zróżnicowany zbiór modeli komunikowania, które można pogrupować w obrębie czterech podstawowych wzorców (McQuail 1994) ${ }^{5}$ :

1) model transmisji - nastawiony na jednokierunkowość przekazu, akcentujący przewagę nadawcy (władza, autorytet, wiedza),

2) model rytuału - podkreśla wspólnotowość, tworzenie więzi, łączność, satysfakcję psychiczną nadawcy i odbiorcy,

3) model przyciągania uwagi - wskazuje na istnienie samego zjawiska komunikowania, faktu komunikowania jako takiego, funkcjonowania w przestrzeni publicznej,

4) model recepcji - zwraca uwagę na kodowanie i dekodowanie przekazu, odmienność interpretacji tych samych zjawisk przez różnych odbiorców ${ }^{6}$.

Przytoczone modele funkcjonują w czterech podstawowych wymiarach komunikacyjnych (Korporowicz 1995: 31-32):

1) wymiar komunikacji międzykulturowej (np. zjawisko globalizacji),

2) wymiar komunikacji wewnątrzkulturowej (np. pytania o wartości ważne w danym kręgu kulturowym),

3) wymiar komunikacji interpersonalnej (np. relacje między konkretnymi osobami we wszystkich sferach życia jednostki: prywatna, publiczna),

4) wymiar komunikacji intrapersonalnej (np. tożsamość jednostki).

Komunikację tworzą zatem systemy wzajemnych powiązań o płynnych i rozpoznawalnych sytuacyjnie strukturach.

\section{Strategie komunikacyjne}

Komunikacja odbywa się dzięki istniejącym strategiom ${ }^{7}$, czyli powtarzalnym, celowym działaniom, zwiększającym efektywność oraz ekonomiczność całości tego procesu. Strategie komunikacyjne dotyczą wszystkich ww. wymiarów komunikacyjnych. Obejmują przekaz norm, wzorców i kodów kulturowych. Podstawę funkcjonowania grup i środowisk stanowi tym samym spójny zbiór reguł

${ }^{5}$ D. McQuail bada komunikację masową, medialną, jednak uwagi te można przetransponować na model komunikacji w szerszym rozumieniu tego pojęcia.

${ }^{6}$ Szerzej na temat pogrupowania bardzo wielu modeli komunikowania w obrębie ww. czterech podstawowych por. Goban-Klas 2002: 53-73. Autor stosuje też własną nominację: 1) model pocisku, 2) model choinki, 3) model magnesu, 4) model klocków (2002: 54) oraz przedstawia autorską propozycję modelu syntetycznego Goban-Klas (2002: 73-77).

7 Autorka niniejszego tekstu zaproponowała koncepcję różnorodnego paradygmatu strategii. Wyróżniła następujące poziomy rzeczywistości: komunikacja - dyskurs - gatunek - tekst. Wskazała, że równolegle z poziomami rzeczywistości występuje hierarchiczny model strategii, obejmujący: strategie komunikacyjne, strategie dyskursu, strategie dyskursywne i strategie tekstowe; funkcjonujący w ramach pewnego kanonu wartości w obrębie danej kultury. Każdemu poziomowi rzeczywistości odpowiada właściwa strategia. Funkcjonowanie na różnych poziomach rzeczywistości ukazuje zależności między różnymi strategiami (Rzeszutko-Iwan 2015: 25-119). 
społecznych ${ }^{8}$, tzn. akceptowanych i uzgodnionych przez ludzi zasad postępowania, uwzględniających możliwe warianty rozwoju sytuacji. Akty komunikacji odbywające się zarówno na poziomie intrapersonalnym, jak i w wymiarze zjawisk globalnych, to zachowania wnoszące wkład w nieustanny proces wymiany, dotyczą kształtowania całej kultury. Komunikowanie to zjawisko zachodzące stale, gdyż milczenie również niesie określoną porcję informacji ${ }^{9}$. Cała sfera społeczna stanowi przestrzeń wzajemnego różnorodnego oddziaływania. Strategie komunikacyjne objawiają się poprzez wspólne uzgadnianie znaczeń, podzielane symbole, sposoby ich interpretacji ${ }^{10}$. Określenia szczególnie ważne pełnią funkcje identyfikacji społecznej, są związane z najważniejszymi wartościami kulturowymi akceptowanymi w danej grupie i środowisku: tradycja, zwyczaje, obyczaje, język. Wszelkie podejmowane czynności pozostają zawsze w odniesieniu do obowiązującego w danej grupie systemu etycznego, moralnego, religijnego, prawnego itp. Może to być relacja potwierdzania bądź negowania istniejących norm. „W naturze ludzkiej drzemie bowiem [...] nie tylko zalążek potrzeby porozumiewania się z innymi, nawiązania z innymi kontaktu, ale także równie «kreatywny» zalążek opcji odwrotnej” (Grucza 1996: 20). Przy czym „odchylenia od określonego kulturowo scenariusza traktowane są jako zakłócenia porządku społecznego" (Nęcki 2000: 36). Możliwe jest jednak również przeformułowanie obowiązujących reguł i ustalenie nowych, przy jednoczesnym przestrzeganiu podstawowego założenia, że istotę funkcjonowania każdej społeczności stanowi respektowanie ważnych dla niej wartości, np. wolności, godności, bezpieczeństwa, sprawiedliwości, prawdy. Przy czym konflikt czy spór nie zawsze muszą być postrzegane w kategoriach zła, którego trzeba unikać, czasami nawet warto je prowokować, gdyż odpowiednio potraktowane i wykorzystane mogą służyć dobru. Mają wtedy konstruktywny (identyfikacja, kreacja, innowacja) charakter ${ }^{11}$.

Dzięki strategiom komunikacyjnym jednostki nabywają doświadczeń w różnych dziedzinach życia, całej przestrzeni kulturowej. Można zatem wyróżnić następujące strategie komunikacyjne ${ }^{12}$ :

${ }^{8}$ Na temat teorii reguł społecznych por. Crushman, Valentinsen, Dietrich 1982.

9 Por. np. Hall 1987. Na temat komunikacji niewerbalnej zob. też m.in. Zaliwska-Okrutna 1996; Hall 2001; Orzechowski 2007; Zimbardo, Gerrig 2012: 149-158.

${ }^{10} \mathrm{Na}$ temat interpretacji wybranych symboli przez przedstawicieli kręgu słowiańskiego, arabskiego i indyjskiego por. np. Rzeszutko 2000, 2001, 2002, 2003.

${ }^{11}$ Zob. np. spostrzeżenia na temat sytuacji komunikacji interkulturowej, odbywającej się poprzez sztukę (Tyszka 1995: 17):

Pomiędzy organizatorami spotkań ze strony Centrum a zaproszonymi z zagranicy gośćmi pojawiały się często nieporozumienia i były one niekiedy wazniejsze i bardziej pouczajace - niz porozumienia.

${ }^{12}$ Należy zaznaczyć, że Leszek Korporowicz wyróżnia trzy strategie komunikacyjne, opierające się na reprodukcji kodu, wzajemnej adaptacji kodów oraz transformacji i kreacji kodu. Szerzej na temat socjologicznej perspektywy ujęcia strategii komunikacyjnych, z uwzględnieniem zagadnień komunikacji interkulturowej zob. Korporowicz 1995. 
1) strategia reprodukcji treści/kodu kulturowego,

2) strategia wzajemnej adaptacji treści/kodów kulturowych,

3) strategia transformacji i kreacji treści/kodu kulturowego.

Strategię reprodukcji treści/kodu kulturowego cechuje przekonanie o niemożliwości wprowadzenia jakiejkolwiek zmiany w istniejącym przekazie kulturowym. Postawę tę cechuje brak reakcji na dokonujące się przemiany, skostnienie zastanych zachowań i przyswojonego obrazu świata, a nawet niezauważanie zachodzących procesów. Takie zablokowanie i uprzedmiotowienie może prowadzić do fetyszyzacji istniejących przekazów kulturowych ${ }^{13}$, które stają się w tej perspektywie wartością autoteliczną. Podejście to neguje możliwość kontaktu z innymi, powoduje brak tolerancji dla odmienności kulturowych ${ }^{14}$. Jednostki zamykają się w granicach skostniałej wizji rzeczywistości, co w konsekwencji prowadzi do destrukcji ich samych oraz ich społecznego, kulturowego środowiska (Jan Paweł II 1991) ${ }^{15}$ :

Jeżeli jakaś kultura zamyka się w sobie i przejawia tendencję do utrwalania przestarzałych obyczajów, odrzucając jakąkolwiek wymianę - i konfrontację [...] to grozi jej jałowość i upadek.

Odmiennie wygląda sytuacja w przypadku strategii wzajemnej adaptacji treści/kodów kulturowych, gdyż oznacza ona podejście uwzględniające zmiany zachodzące w środowisku kulturowym. W ramach tej strategii występują zachowania zmierzające do pewnych modyfikacji i przekształceń kodów ${ }^{16}$. Współpraca okazuje się jednak tylko zjawiskiem pozornym, gdyż modyfikacje i przekształcenia dotyczą wyłącznie aspektów powierzchownych. Zatem brak autentycznej akceptacji dla głoszonych idei może powodować wewnętrzne sprzeczności, a nawet zaburzenia tożsamości kulturowej. Dokonujące się zmiany nie mają zakorzenienia i osadzenia w zinterioryzowanym systemie wartości społecznych i kulturowych. Komunikacja staje się powierzchowna, co stanowi potencjalne źródło ukrytych napięć i konfliktów ${ }^{17}$.

Strategia transformacji i kreacji treści/kodu kulturowego jest natomiast najbardziej skomplikowanym i złożonym procesem. Nastawienie na rejestrowanie zachodzących zmian kulturowych i przekonanie o konieczności reagowania na nie prowadzi do komunikacji autentycznej. Warunek zaistnienia tej strategii stanowi rzeczywista świadomość akceptowanego systemu wartości, własnej tożsamości

13 Por. np. język czy wzorce zachowań kulturowych pielęgnowane na emigracji, niefunkcjonujące w kraju pochodzenia; Mickiewicz 1834; Markowski 1992: 171-177.

${ }^{14} \mathrm{Na}$ temat postaw, dyspozycji, orientacji w kontekście kontaktów kulturowych por. Wielecki 1995

${ }^{15}$ Cyt. za Misiaszek 1995:165.

${ }^{16}$ Np. zagadnienie atrakcyjnej amerykanizacji (Ożóg 2002); zmiany polskich tradycji świątecznych (Grybosiowa 2002).

17 Por. zagadnienie akulturacji, enkulturacji, asymilacji, stereotypu, sytuacje pogranicza narodowościowego, kulturowego; Wróblewska-Pawlak 1995; Grucza 1996; Traba red. 2009, 2012. 
kulturowej oraz osadzenia w konkretnym kręgu kulturowym. Tożsamość kulturowa i tożsamość wartości jawią się bowiem jako nieodzowne elementy umożliwiające właściwe reagowanie na zachodzące zmiany ${ }^{18}$. Reguła autotransformacji jest bowiem procesem ciągłego wyboru, a także nieustannego określania samego siebie. Realizujące się tu zjawisko synergii wskazuje na fakt, że nowa jakość nie jest tylko prostą sumą elementów istniejących uprzednio. W przypadku tej strategii we wszystkich wymienionych wymiarach komunikacji zachodzą zjawiska reintegracji, rekonfiguracji i hybrydyzacji treści kulturowych. Wielość, zmienność, dekompozycja to jednocześnie typ zdolności, cechujący zarówno jednostki, jak i całe społeczności, leżący u podstaw omawianej strategii, umożliwiający zarazem zaistnienie autentycznej integracji i dialogu. Otwarty, lecz jednocześnie selektywny stosunek wobec nowych zjawisk, oraz twórcza reakcja na nie mają wpływ na autonomiczne samookreślenie podmiotów, zaś „odnalezienie siebie w dynamice zjawisk [...] wymaga dużego wysiłku, który może być podjęty jedynie na podstawie wyraźnie wykształconych dyspozycji” (Korporowicz 1995: 35). Wyłącznie jednostki o otwartej osobowości, reagujące na zmiany mogą dokonywać przeobrażeń, a także podlegać twórczym procesom autotransformacyjnym w kontekście dynamicznie zachodzących zjawisk kulturowych.

Podsumowując:

strategia reprodukcji treści prowadzi do petryfikacji kodów kulturowych, a w konsekwencji uniemożliwia komunikację. Strategia wzajemnej adaptacji treści umożliwia funkcjonalne podejście do kodów kulturowych, może jednak prowadzić do powierzchownej komunikacji, nadinterpretacji przekazu, tymczasowości zachowań, nabywania zachowań modnych. Zaś strategia transformacji i kreacji treści przybiera charakter interakcyjno-rozwojowy ${ }^{19}$. Jest zjawiskiem niezwykle skomplikowanym, gdyż w procesie komunikacji kultur pomimo podobieństw powierzchniowych istnieją odmienności głębokich poziomów wartości, norm i wzorców (Rzeszutko-Iwan 2015: 124).

Członkowie grup społecznych w wyniku interakcji komunikacyjnych wnoszą jednocześnie permanentny wkład w rozwój i kształt całego systemu kulturowego. Formułują i ustalają nowe reguły, prowadzące do zmiany pojmowanej w kategoriach rozwoju:

W różnych kulturach istnieją ograniczenia co do swobody nawiązywania kontaktów społecznych z innymi osobami - kasty, klasy, warstwy, religie itd. służą między innymi temu celowi. Niemniej segregacja społeczna zdaje się zanikać, a wolność nawiązywania kontaktów i określania poziomu ich intymności zależy od woli partnerów (Nęcki 2000: 25$)^{20}$.

${ }^{18}$ Zob. też kwestie identyfikacji kulturowej, kształtowania tożsamości, zjawiska submersji (zatopienia) i immersji (zanurzenia) kulturowej; Wróblewska-Pawlak 1995: 70-76.

${ }_{19} \mathrm{Na}$ temat sposobów funkcjonowania identyfikacji kulturowych por. m.in. Korporowicz 1995: 36-40; Traba red. 2009, 2012.

${ }^{20}$ Por. też Watzlawick, Beavin, Jackson 1967; Fisher 1982. 
Jednak pojawiają się również poważne zagrożenia w sytuacji komunikowania się głównie w wymiarze międzykulturowym, wewnątrzkulturowym i interpersonalnym. Taktyka utrzymania ,pokoju przez zrozumienie”, ,kształcenie dla pokoju", gromadzenie potencjalnych nieprzyjaciół przy stole konferencyjnym, zwracanie uwagi na precyzję myślenia, poprawę komunikacji, edukację, idea naturalnej harmonii interesów, gdy usunięte zostaną nieporozumienia okazuje się w pewnych sytuacjach nieskuteczna (Garnett 2009; Kuźniar 2009); co bardzo wyraźnie potwierdza obecna sytuacja międzynarodowa.

Nie można w tym miejscu nie wspomnieć zatem o postawach ${ }^{21}$, które wprowadzają zakłócenia w procesie komunikacji. Utrudniają przepływ i przekaz informacji w przestrzeni kulturowej. Należą do nich:

1) ekskluzywizm,

2) inkluzywizm,

3) paralelizm.

Ekskluzywizm to postawa uznająca, iż jedynie słuszne i godne upowszechniania są indywidualne poglądy i przekonania. Inkluzywizm to predyspozycja charakteryzująca się cząstkowym, wybiórczym i wyrywkowym włączaniem poglądów innych we własny system przekonań. Paralelizm zaś stanowi postawę, cechującą jednostki, które jednocześnie nie negują oraz nie akceptują poglądów innych grup oraz społeczności. Uznają tym samym możliwość równoległego istnienia wielu interpretacji i wizji rzeczywistości. Konsekwencją ww. postaw jest przekonanie członków określonej wspólnoty kulturowej o samowystarczalności, atomizacja oraz zamknięcie tejże wspólnoty. Gdy pojawiają się tendencje „centryczne", niechęć do uświadamiania sobie i wyzbywania się uprzedzeń, pokusa upraszczania, a także brak empatii, przytoczone uprzednio hasła UNESCO (m.in. utrzymania „pokoju przez zrozumienie”, „kształcenie dla pokoju”), okazują się niemożliwe do realizacji. Bowiem jak stwierdza John Garnett (2009: 33), nigdy nie znamy prawdziwych intencji drugiej strony, ani ona naszych i nigdy nie możemy wniknąć w lęk drugiego przed nami, ani on - w nasz.

Zatem funkcją strategii komunikacyjnych jest permanentne ustanawianie i utrzymywanie pożądanych stosunków we wszystkich wymiarach komunikacji. Wymienione wyżej typy strategii (strategia reprodukcji treści/kodu kulturowego, strategia wzajemnej adaptacji treści/ kodów kulturowych) oraz postawy utrudniające przepływ i przekaz informacji w przestrzeni dyskursywnej (ekskluzywizm, inkluzywizm, paralelizm) wpisują się w model komunikacji charakteryzujący się dążeniem uczestników interakcji do przekonania innych, aby „ujrzeli rzeczy ich oczyma" (Casmir 1996a: 29).

W ramach przedstawionych strategii komunikacyjnych można jednocześnie wskazać kroki strategiczne, które powinny prowadzić w stronę autentycznej, efektywnej komunikacji i dialogu:

${ }^{21}$ Szerzej na temat ww. postaw w kontekście dialogu autentycznego zob. Kozłowski 1990: $74-77$. 
1) uświadomienie sobie własnej odrębności, inności,

2) odkrycie własnej reguły transformacji,

3) umiejętność twórczej reinterpretacji własnego dziedzictwa kulturowego, myślowego, społecznego,

4) kompetencja w zakresie nieustannej reintegracji i wymiany doświadczeń różnych kultur,

5) dekompozycja zastanych standardów kulturowych, myślowych, społecznych.

Prawdziwy dialog 22 oznacza bycie $\mathrm{w}$ relacji $\mathrm{z}$ innym. Wiąże się $\mathrm{z}$ brakiem przekonania o aprioryczności własnych poglądów i interpretacji, a nawet nastawieniem samokrytycznym. Wymaga odwagi, gdyż partnerzy, otwierając się na siebie, podejmują ryzyko i nie wiedzą, jaki będzie finał tego procesu. Wspólne poszukiwania mogą bowiem doprowadzić do zmiany własnych zapatrywań i poglądów. Zamiast panowania i przewagi, dychotomii mówca - słuchacz, pojawia się interakcyjny obopólnie korzystny twórczy proces wymiany ${ }^{23}$.

Należy tym samym mocno podkreślić, że istota autentycznej komunikacji opiera się na jednostkach o otwartej, zdolnej do rozwoju osobowości, cechujących się umiejętnością zachowania dystansu wobec własnej kultury ${ }^{24}$. Przestrzeganie norm moralnych, etycznych, kulturowych, stosowanie prawa kształtuje pożądane zachowania społeczne. Wpływa na zachowania ludzi oraz formułuje pożądane postawy i nakłania do akceptacji uznawanych wartości. Strategie komunikacyjne służą więc realizacji nadrzędnego, ogólnego celu, jakim jest dążenie do zachowania i utrzymania ładu rzeczywistości, ustanawianie i utrzymywanie pożądanych stosunków w ramach określonej wspólnoty kulturowej, eliminowanie zachowań zagrażających uznawanym wartościom oraz nakłanianie do działań chroniących te wartości.

Dialog i współpracę w procesie komunikacji można zatem osiągnąć poprzez uczestnictwo, wspólne budowanie, zespolenie. Zjawiska takie zachodzą przy zastosowaniu strategii transformacji i kreacji treści/kodu kulturowego, a ich podstawę stanowi zinterioryzowany system norm i wartości, samoidentyfikacja oraz określenie własnego miejsca w historii i przestrzeni kulturowej, a także sposób postrzegania innych grup oraz ich odmienności. Przy czym złożoność i zmienność nie wyklucza stabilności komunikacyjnej, gdyż dzięki wspólnemu fundamentowi podzielanych wartości można utrzymać równowagę i harmonię między „dynamizmami tworzącymi sferę wspólnoty oraz sferę odrębności” (Smolicz 1996: 110).

22 Andrzejewski red. 1990; Kozłowski 1990: 74-77; Casmir 1996a: 41-42.

${ }^{23}$ W kontekście komunikacji interkulturowej Fred Casmir (1996a: 45-51) operuje pojęciem tzw. cyklu spełnienia, obejmującego: doświadczenia, które wytwarzają potrzeby, powodujące następnie podjęcie interakcji, komunikacji, prowadzącej w konsekwencji do zaistnienia wspólnych korzyści. Osiągnięty stan nazywa „wzajemnością”, „współistotnością”, „trzecią strefą”. Jest on korzystny dla obydwu stron, oparty na współpracy i niestwarzający sytuacji zagrożenia. Wymaga jednak nieustannego negocjowania znaczeń.

${ }^{24}$ Por. też Wlazło 2003; Iwan i in. red. 2003. 
Należy zatem jeszcze raz mocno podkreślić, że nie jest możliwe istnienie żadnej organizacji czy kultury bez komunikacji, która stanowi jedyny sposób ustanawiania i utrzymywania relacji społecznych.

\section{Bibliografia}

Andrzejewski B. (red.), 1990, Komunikacja-rozumienie - dialog, Poznań.

Arystoteles, 1988, Retoryka, Warszawa.

Carey J., 1989, Communication as Culture. Essays on Media and Society, Boston.

Casmir F., 1996a, Budowanie trzeciej kultury: zmiana paradygmatu komunikacji międzynarodowej i międzykulturowej, w: Komunikacja międzykulturowa. Zderzenia i spotkania, red. A. Kapciak, L. Korporowicz, A. Tyszka, Warszawa, s. 28-57.

Casmir F., 1996b, Komunikacja ludzka w perspektywie wielokulturowej, w: Komunikacja międzykulturowa. Zderzenia i spotkania, red. A. Kapciak, L. Korporowicz, A. Tyszka, Warszawa, s. 11-28.

Cushman D., Valentinsen B., Dietrich D., 1982, A Rules Theory of Interpersonal Relationships, w: Human Communication Theory - Comparative Essays, red. F. Dance, New York, s. 90-107.

Dobek-Ostrowska B., 2002, Podstawy komunikowania społecznego, Wrocław.

Fisher A., 1982, The Pragmatic Perspective of Human Communication. A View from System Theory, w: Human Communication Theory, red. F. Dance, New York, s. 192-219.

Garnett J., 2009, Przyczyny wojny i warunki pokoju, w: Strategia we wspótczesnym świecie. Wprowadzenie do studiów strategicznych, red. J. Baylis, J. Wirtz, C.S. Gray, E. Cohen, Kraków, s. 19-43.

Goban-Klas T., 2002, Media i komunikowanie masowe. Teorie $i$ analizy prasy, radia, telewizji i Internetu, Warszawa.

Grucza F., 1996, O przeciwstawności ludzkich interesów i dązeń komunikacyjnych, interkulturowym porozumiewaniu się oraz naukach humanistyczno-społecznych, w: Problemy komunikacji interkulturowej: Jedna Europa - wiele języków i wiele kultur, red. F. Grucza, K. Chomicz-Jung, Warszawa, s. 11-33.

Grybosiowa A., 2002, Laicyzacja i okcydentalizacja polskiej tradycji światecznej jako symbolu XX wieku, w: Składnia - stylistyka - struktura tekstu, red. M. Krauz, K. Ożóg, Rzeszów, s. 13-18.

Habermas J., 1999, Teoria działania komunikacyjnego, t. 1, Warszawa.

Habermas J., 2002, Teoria działania komunikacyjnego, t. 2, Warszawa.

Hall E., 1987, Bezglośny język, Warszawa.

Hall E., 2001, Poza kultura, Warszawa.

Iwan K., Komorowska H., Rella A., Życzak J. (red.), 2003, Dialog kultur w Nowej Europie. Literatura. Język. Historia, Szczecin.

Jan Paweł II, 1991, Centesimus annus, Wrocław.

Kaczmarek B., 2009, Misterne gry w komunikacje, Lublin.

Korporowicz L., 1995, Od konfliktu do spotkania kultur, czyli tożsamość jako reguła autotransformacji, w: Komunikacja międzykulturowa. Zbliżenia $i$ impresje, red. A. Kapciak, L. Korporowicz, A. Tyszka, Warszawa, s. 31-43.

Kozłowski R., 1990, O pojęciach i funkcjach dialogu, w: Komunikacja - rozumienie dialog, red. B. Andrzejewski, Poznań, s. 69-77. 
Kudra B., 2014, O komunikacji społecznej, w: Komunikowanie publiczne. Zagadnienia wybrane, red. B. Kudra, E. Olejniczak, Łódź, s. 9-25.

Kuźniar R., 2009, Przedmowa do wydania polskiego, w: Strategia we współczesnym świecie. Wprowadzenie do studiów strategicznych, red. J. Baylis, J. Wirtz, C.S. Gray, E. Cohen, Kraków, s. XXII-XXVII.

Markowski A., 1992, Polszczyzna końca XX wieku, Warszawa.

McQuail D., 1994, Mass Communication Theory. An Introduction, London.

Mickiewicz A., 1834, Pan Tadeusz, Paryż.

Misiaszek K., 1995, Kościół a dialog międzykulturowy, w: Komunikacja międzykulturowa. Zblizenia i impresje, red. A. Kapciak, L. Korporowicz, A. Tyszka, Warszawa, s. $159-168$.

Nęcki Z., 2000, Komunikacja międzyludzka, Kraków.

Orzechowski S., 2007, Komunikacja niejęzykowa a wiarygodność, Lublin.

Ożóg K., 2002, Atrakcyjna amerykanizacja w kulturze polskiej $i w$ języku polskim, w: Składnia - stylistyka - struktura tekstu, red. M. Krauz, K. Ożóg, Rzeszów, s. 18-27.

Rzeszutko M., 2000, Semantyka symboli $w$ dialogu kultur, „Poradnik Językowy”, z. 4, s. $1-12$.

Rzeszutko M., 2001, Sposoby rozumienia wybranych symboli przez przedstawicieli róznych nacji. Zeszyty Naukowe Wyższej Szkoły Pedagogicznej w Rzeszowie, Seria Filologiczna, Językoznawstwo 6, z. 39, Rzeszów, s. 59-71.

Rzeszutko M., 2002, Symbol w komunikacji interkulturowej, w: Beiträge der Europäischen Slavistischen Linguistik (POLYSLAV), t. 5, (Die Welt der Slaven, Sammelbände) Сборник, 15), Hrsg. R. Blankenhorn, S. Dönninghaus, R. Marzari, München, s. 200-210.

Rzeszutko M., 2003, Dialog Stowian - na przykładzie wybranych symboli, w: Świat Stowian w języku i kulturze IV, Językoznawstwo, red. E. Komorowska, Ż. Kozicka-Borysowska, Szczecin, s. 257-267.

Rzeszutko-Iwan M., 2015, Zarys paradygmatu strategii w przestrzeni dyskursu publicznego (przestuchania sąowe a/i wywiady radiowe), Lublin.

Skibiński A., 2003, Homo Significus, Warszawa.

Smolicz J., 1990, Język jako wartość podstawowa kultury, w: Język polski w świecie, red. W. Miodunka, Kraków, s. 23-38.

Stalmaszczyk P., Cap P. (red.), 2014, Pragmatyka, retoryka, argumentacja: obrazy języka $i$ dyskursu w naukach humanistycznych, Kraków.

Szacka B. (red.), 1991, Człowiek, zwierzę społeczne, Warszawa.

Traba R. (red.), 2009, Stereotypy i pamięć, t. 1, seria Akulturacja/asymilacja na pograniczach kulturowych Europy Środkowo-Wschodniej w XIX $i$ XX wieku, Warszawa.

Traba R. (red.), 2012, Sasiedztwo polsko-niemieckie, t. 2, seria Akulturacja/asymilacja na pograniczach kulturowych Europy Środkowo-Wschodniej w XIX i XX wieku, Warszawa.

Tyszka A., 1995, Rozmowa kultur. Założenia i rezultaty seminarium „,Komunikacja międzykulturowa 1992-93”, w: Komunikacja międzykulturowa. Zbliżenia i impresje, red.

A. Kapciak, L. Korporowicz, A. Tyszka, Warszawa, s. 5-31.

Watzlawick P., Beavin J., Jackson D., 1967, Pragmatics of Human Communication, New York.

Wielecki K., 1995, Kompetencje do komunikacji międzykulturowej: problemy polityczne i edukacyjne, w: Komunikacja międzykulturowa. Zbliżenia i impresje, red. A. Kapciak, L. Korporowicz, A. Tyszka, Warszawa, s. 115-122. 
Wlazło M., 2003, Współczesne aplikacje koncepcji dialogu międzykulturowego w filozoficznej hermeneutyce Hansa-Georga Gadamera (1900-2002), w: Dialog kultur w Nowej Europie. Literatura. Język. Historia, red. K. Iwan, H. Komorowska, A. Rella, J. Życzak, Szczecin, s. 128-137.

Wróblewska-Pawlak K., 1995, Dwujęzyczność a dwukulturowość, w: Komunikacja międzykulturowa. Zbliżenia i impresje, Warszawa, red. A. Kapciak, L. Korporowicz, A. Tyszka, s. 69-78.

Zaliwska-Okrutna U., 1996, Językoznawcze teorie przyswajania języka a psychologiczne i kulturowe uwarunkowania komunikacji międzyludzkiej, w: Problemy komunikacji interkulturowej: Jedna Europa - wiele języków i wiele kultur, Warszawa, red. F. Grucza, K. Chomicz-Jung, s. 33-41.

Zimbardo P., Gerrig R., 2012, Psychologia i życie, Warszawa.

Żydek-Bednarczuk U., 2005, Wprowadzenie do lingwistycznej analizy tekstu, Kraków. 